\title{
Krešimir Peračković
}

\section{Društvena uloga znanstvenika danas}

\section{Znanstvenik kao homo economicus i homo sociologicus versus homo academicus universalis}

\begin{abstract}
Sažetak
U radu se kritički propituju neki aspekti uloge znanstvenika u suvremenom društvu, polazeći od različitih očekivanja spram znanstvenika pod različitim vanjskim pritiscima: scijentometrije, društvene odgovornosti $i$ humanističke zadaće. U tom razmatranju društvenog okvira i normi koje usmjeravaju djelovanje znanstvenika, najprije će se ukratko prikazati mogući pristupi ulogama znanstvenika kao homo economicusa i homo sociologicusa, što će poslužiti kao ideal-tipski predlošci za razvoj modela u kojem se analiziraju obje uloge znanstvenika kroz obilježja korisnosti, dobiti i racionalnosti na individualnoj, organizacijskoj i socio-političkoj razini. Nakon toga će se prikazati i integrativni model homo academicus universalis, koji integrira i pomiruje obilježja prethodnih te donosi i neke stare humanističke ideale znanstvenika kao univerzalnog čovjeka. Na kraju će se ukratko analizirati $i$ društveni kontekst: tržišno društvo $u$ kojem je prevladavajuća tendencija da se i znanost $u$ potpunosti komodificira.
\end{abstract}

\section{Ključne riječi}

homo economicus, homo sociologicus, homo academicus universalis, komodifikacija znanja, društvo znanja, tržišno društvo, sociologija znanosti

\section{Uvod}

Ako pođemo od činjenice da se suvremena uloga znanstvenika u društvu, odnosno njegova zadaća značajno promijenila od starogrčkih ideala filozofa-znanstvenika (Ben-David, 1971) pa od srednjovjekovnog ideala naučenjaka sa znanjem septem artes liberales ${ }^{1}$ (Parker, 1890; Curtius, 1948; Wagner, 1983) kao i od postrevolucionarnih i prosvjetiteljskih ideala i vjere u racionalno, empirijsko i znanstveno s početka 19. stoljeća, postavlja se pitanje do čega je ta promjena dovela i koji su danas glavni principi prema kojima se formiraju i znanstvenici kao osobe, ali i znanstvene institucije te znanost kao društveni sustav i koji kriteriji ih formiraju. Odgovore možda možemo nazrijeti između ostalog i među ključnim mjerilima kojima se vrednuju i ocjenjuju znanstvenici danas, mjerilima izvrsnosti, međunarodne vidljivosti i slično koja pokazuju koliko su puta citirani (isključujući samocitiranje), koliko imaju

Artes liberales ili liberal arts (slobodna umijeća) je pojam koji je u antičko doba značio studij gramatike, logike i retorike (trivium). U srednjem vijeku dodan je i quadrivium: studij aritmetike, geometrije, glazbe i astronomije, što je zajedno činilo takozvani sustav septem artes liberales. 
objavljenih radova u uglednim međunarodnim časopisima, kakav je njihov impact factor; koliko imaju radova u CC-u, koliki im je $h$-indeks, na koliko su prestižnih međunarodnih konferencija bili itd. To su samo neka od najvažnijih pitanja i imperativa s kojima se svakodnevno susreću današnji znanstvenici i sveučilišni profesori širom svijeta, a koja su postala najvažniji kriteriji njihovog vrednovanja i temelji evaluacije za njihovo napredovanje ili trajno zaposlenje. Na temelju tih kriterija, znanstvenici usmjeravaju i svoje karijere dugoročno, ali i organiziraju svoje poslove na dnevnoj bazi. A o odgovorima na ta pitanja ovisi sve: motivacija, odabir teme za istraživanje, planiranje poslova, upravljanje karijerom znanstvenika i slično. Scijentometrija je postala novi univerzalni princip prihvaćen nekritički i u društvenim i humanističkim znanostima koje su po prirodi više orijentirane na lokalne probleme, a ne na univerzalne fenomene kao prirodne znanosti pa je znatno teže objaviti znanstveni rad u prestižnom stranom časopisu. Zbog tog scijentometrijskog imperativa nerijetko se odustaje od istraživanja i pisanja o tim lokalnim i regionalnim problemima jer u međunarodnim časopisima slabije kotiraju. Dugoročno, takav pristup reducira ciljeve bavljenja znanošću, a njezinu lokalnu društvenu i javnu odgovornost stavlja implicitno u drugi plan. A taj se trend očituje sve više i u perifernim i nerazvijenim zemljama koje nastoje pratiti razvojne trendove suvremene znanstvene produkcije najrazvijenijih zemalja, a pri tome su bez propitivanja preuzele modele za koje nemaju niti financijska sredstva, niti ljudske resurse. Ako scijentometrija nameće kvantitativnost, racionalnost i korisnost, može se reći da suvremeni znanstvenik u toj ulozi mora djelovati i ponašati se dobrim djelom kao homo economicus i to iz više razloga. Bez obzira što je taj znanstvenik privatno može biti izuzetno društveno odgovorna, nesebična i altruistična osoba, u svojem akademskom obrazovanju i kasnijem djelovanju, prvenstveno je orijentiran prema tim scijentometrijskim kriterijima, postajući tako akter čije vrednovanje se mjeri primarno kvantitativnim pokazateljima, a manje kvalitativnim i od kojega se sve više očekuje kada osmišljava svoje projekte, da treba stvoriti nešto korisno, efikasno, racionalno i s većom dodanom vrijednošću. Osim toga, znanstvenik djeluje i ima određenu ulogu i društveni status u konkretnom društvu (koje pak u svojoj kulturi ima sasvim određenu hijerarhizaciju društvenih vrijednosti i normi koje se kroz proces socijalizacije nastoje internalizirati na pojedince kao članove društva), od čega ni znanstvenici nisu izuzeti kao ni njihova uloga. Takvu društvenu ulogu Boudon opisuje terminom homo sociologicus te još dodaje kako on ne radi uvijek ono što bi želio raditi, nego ono što ga običaji, internalizirane vrijednosti i u općenitom smislu različita etička, kognitivna ili druga uvjetovanja prisiljavaju činiti (Boudon, 1981).

U posljednja dva desetljeća intenzivnije se propituju suvremene društvene funkcije znanosti i njihova proturječja bilo kroz koncept društva znanja ili komodifikacije znanja u kojem se znanstvena spoznaja ili rezultat nekog znanstvenog istraživanja tretira prvenstveno kao roba na tržištu (Slater i Tonkiss, 2004; Castells, 2000), bilo iz kritičke i humanističke perspektive u kojoj je naglasak na znanosti kao javnom ili općem dobru i gdje se govori i o zabludama društva znanja (Milardović, 2011; Nussbaum, 2010; Liessmann, 2008). No u ovom radu ne možemo dati temeljitiji pregled dosad napisanog o tome $\mathrm{i}$ za to bi bila adekvatnija izrada jedne temeljitije bibliografije, ipak treba barem spomenuti i neke domaće autore i najznačajnije radove koji su se bavili ovom temom i navedenim prijeporom ili čak iluzijama o društva znanja (Polšek, 2015; Milardović, 2011; Švarc, 2009), kao i nekim drugim važnim temama o suvremenoj ulozi znanosti i njezinom mogućem ili nužnom holizmu, multidisciplinarnosti, pluriperspektivnosti i integrativnosti u znanosti i obrazova- 
nju (Jurić, 2012). Tu proturječnost između dviju različitih koncepcija i uloge znanosti, Milardović primjerice stavlja u kontekst današnjeg informacijskog i umreženog društva u kojemu se raspravlja zapravo o dvjema strategijama: prva je »strategija neoliberalnog tržišnog i informacionalističkog kapitalizma u kojem je društvo znanja trgovačka kategorija te se ono kupuje i prodaje, a druga je strategija i zagovor slobodnog pristupa znanju koje pripada svima« (Milardović, 2011, 223). Po tome se također razlikuju i dva modela gospodarstva prisutna u Europi, kako nadalje ističe Milardović: model neoliberalnog gospodarstva u kojemu se informacije, znanje, obrazovanje i znanost tretiraju kao roba, a drugi je model socijalno-tržišnog gospodarstva koji je bliži tradiciji i povijesti europskih društava.

Budući da je u navedenim radovima glavni predmet znanje, znanost i/ili obrazovanje, u ovom se radu želi ići drugim pravcem i razmotriti društvene uloge samog znanstvenika (u sociološkom smislu značenja društvene uloge) ${ }^{2}$ koji se nužno suočava s navedenim suprotstavljenim principima znanosti, a koji ga zapravo dovode pred izbor između etike javne odgovornosti i etike dobiti. U tom razmatranju društvenog okvira i normi koje usmjeravaju djelovanje i rad znanstvenika danas, najprije će se ukratko prikazati mogući pristupi ulogama znanstvenika kao homo economicusa i homo sociologicusa koji će poslužiti kao ideal-tipski predlošci za razvoj modela u kojem se analiziraju uloge znanstvenika kroz obilježja korisnosti, dobiti i racionalnosti na individualnoj, organizacijskoj i društveno-političkoj razini. Nakon toga će se prikazati, točnije tj. predložiti i integrativni model homo academicus universalis koji integrira $\mathrm{i}$ pomiruje neka obilježja prethodnih te donosi i neke stare humanističke ideale znanstvenika kao univerzalnog čovjeka. Na kraju će se ukratko analizirati i kontekst, a to je tržišno društvo u kojem je prevladavajuća tendencija da se i znanost $\mathrm{u}$ potpunosti komodificira.

\section{Znanstvenik kao homo economicus: iracionalnost racionalnog izbora}

Bez detaljnog ulaženja u povijest ovog koncepta, jer danas već postoje i čitave studije o nastanku i podrijetlu termina homo economicus (npr. Dixon, Wilson, 2012; O’Boyle, 2007; Persky, 1995) odnosno ekonomski čovjek, ${ }^{3}$ srž te ideje jest pretpostavka o antropološkom određenju čovjeka kao racionalnog i po prirodi sebičnog aktera koji želi maksimizirati korisnost kao potrošač i profit kao proizvođač. Iako su neki autori već davno proglasili kraj koncepta homo economicusa (npr. Drucker, 1939; O’Boyle, 2007), a brojni su ga ponovno oživjeli (Archer i Tritter, 2000; Henrich, Boyd, Bowles, Camerer, Fehr, et al. 2001), ključno pitanje više nije je li racionalnost ljudskog bića motivirana sebičnošću (Smith, 1852; Mill, 1836) ili kognitivnim sposobnostima kalkulacije (Weber, 1978), nego su pitanja kada, gdje i kako je taj koncept preživio te postao društvena norma ili pravilo, pa čak i zakon koji regulira djelovanje

2

Društvena uloga je jedan od temeljnih socioloških pojmova, a definira se kao »skupina normi koje određuju kakvo se ponašanje očekuje od pojedinca koji zauzima određeni status« (Haralambos, Heald, 1989).

J. Persky u svojem radu The Ethology of Homo Economicus naglašava da je glavni sa- držaj pojma ekonomski čovjek zapravo tema iz eseja J. S. Milla iz 1836. On the Definition of Political Economy and On the Method of Investigation Proper to It. U njemu Mill opisuje četiri osnovna ljudska interesa: akumulaciju, dokolicu, luksuz i prokreaciju (Persky, 1995, 222). 
pojedinca, organizacije ili čitavog društva. Ne ulazeći u pregled svih kritičkih rasprava na tu temu, važno je istaknuti da je taj koncept nadišao ekonomsku sferu društva i proširio se na političku i sociokulturnu sferu, i postao temelj suvremene političke filozofije razvijenih zapadnih zemalja pretočen u ideologiju liberalnog kapitalizma, u kojima su društva postala puki privjesak tržišta (Polanyi, 1944) odnosno tržišna društva (Slater, Tonkiss, 2004; Peračković 2008).

Prema tom konceptu, znanstvenik se na osobnoj razini ponaša kao HE, organizacija je dizajnirana po principima HE, a znanstveni sustav nagrađuje, potiče i financira projekte prema istom kriteriju. Znanstvene institucije na najvišim državnim razinama poput ministarstva ili specijaliziranih agencija drže se upravo načela HE prema kojima se znanstvenik mora ponašati poput racionalnog i kalkulabilnog stručnjaka čiji ciljevi u znanosti moraju obuhvaćati povećanje neke (financijske) korisnosti, najčešće praćenu porastom dobiti jer rezultati istraživanja trebaju poslužiti donositelju odluka tj. naručitelju za povećanje dobiti. U tom se smjeru rade i napuci za evaluaciju znanstvenih programa i projekata kako na nacionalnoj, tako i na internacionalnoj razini, u kojima sve više dominira kriterij ekonomske korisnosti za privredni sektor. Teorija korisnosti tako postaje temeljno načelo implementirano u znanstvene politike najrazvijenijih zemalja, iako je u retorici prisutnija teorija izvrsnosti. No nisu sporni racionalnost i korisnost po sebi, nego je problem to što ovdje nisu usmjereni na korist općeg dobra, nego prije svega u korist aktera novca, moći i vlasti. Stoga je pitanje, ako je racionalnost metoda povećanja efikasnosti nekog djelovanja, a plodovi su više novca, uspjeha i ugleda, tko su glavni dobitnici te postaje li racionalnost time zapravo društveno iracionalna. U Tablici 1 prikazan je ideal-tipski model znanstvenika kao HE u kojem se analiziraju obilježja korisnosti, dobiti i racionalnosti na individualnoj, organizacijskoj i društveno-političkoj razini.

Tablica 1. Model znanstvenika kao homo economicusa

\begin{tabular}{|l|l|l|l|}
\hline \multicolumn{1}{|c|}{ Korisnost } & \multicolumn{1}{c|}{ Dobit } & \multicolumn{1}{c|}{ Racionalnost } \\
\hline Individualna razina & $\begin{array}{l}\text { Osobni ugled } \\
\text { Društveni status } \\
\text { Uspješnost }\end{array}$ & $\begin{array}{l}\text { Napredovanje i } \\
\text { trajno zaposlenje }\end{array}$ & $\begin{array}{l}\text { Kvantifikacija i kalkulacija } \\
\text { (broj publikacija, } \\
\text { indeksiranost, citiranost) }\end{array}$ \\
\hline $\begin{array}{l}\text { Organizacijska } \\
\text { razina }\end{array}$ & $\begin{array}{l}\text { Znanstvenik kao } \\
\text { ljudski resurs }\end{array}$ & $\begin{array}{l}\text { Povećanje profita } \\
\text { i/ili ugleda za } \\
\text { organizaciju }\end{array}$ & $\begin{array}{l}\text { Reakreditacija } \\
\text { Dobivanje sredstava za } \\
\text { projekte }\end{array}$ \\
\hline $\begin{array}{l}\text { Društvena/politička } \\
\text { razina }\end{array}$ & $\begin{array}{l}\text { Ukidanje sredstava za } \\
\text { »beskorisne« znanosti }\end{array}$ & Znanje kao roba & $\begin{array}{l}\text { Scientometrija kao } \\
\text { normativ }\end{array}$ \\
\hline
\end{tabular}

\section{Znanstvenik kao homo sociologicus - društvena uloga i kulturalni determinizam}

Iako je u literaturi koncept homo sociologicus (HS) često predstavljen kao suprotnost konceptu HE (Dahrendorf, 1961; Boudon, 1981; Hamlin, 2012), činjenica je da se sadržajno više nadopunjuju nego što se suprotstavljaju. Suprotnost HE je zapravo više koncept homo reciprocans prema kojemu su ljudska bića primarno motivirana željom da međusobno surađuju i poboljšavaju kvalitetu života, pri čemu je recipročnost, a nipošto ne sebičnost, prvi temelj ljudske motivacije (Fehr, Gächter, 1998). Dahrendorfov i Boudonov HS zapravo označava model ljudske prirode koja je uglavnom determinirana društvenim snagama koje mu nameću vrijednosti i ukuse kroz procese soci- 
jalizacije. Dahrendorf govori o HS kao o slici ljudske prirode prikazanoj u nekim sociološkim modelima, ograničenom onim društvenim snagama koje determiniraju individualne ukuse i društvene vrijednosti, čime individua kao pojam biva teorijski mrtva (Dahrendorf, 1961, 203). Boudon pak ističe da HS ne radi uvijek ono što bi želio raditi, nego ono što ga običaji, internalizirane vrijednosti $i$ u općenitom smislu različita etička, kognitivna ili druga uvjetovanja prisiljavaju činiti (Boudon, 1981, 56). Prema tome, ako je HE uvjetovan ljudskom prirodom u kojoj prevladava racionalno i sebično biće, HS je uvjetovan društvenim vrijednostima i normama, a sami akterovi izbori barem su djelomično determinirani strukturom situacije i njegovim položajem u njoj. Hirsch i suradnici ističu da je HS zapravo tabula rasa po kojoj društva i kulture pišu vrijednosti i ciljeve te, za razliku HE, on ne djeluje tako da ispuni sebične interese, nego društvene uloge (Hirsch, Michaels, Friedman, 1990).

Prema tome, ako primijenimo i ovaj model u razmatranje pozicije današnjih znanstvenika, također možemo uočiti svojevrsni izvanjski pritisak i očekivanja koja znanstvenik treba ispuniti u nekom društvu. Znanstvenik je pritisnut između moralne obveze javnog djelovanja i tradicionalnih normi, s jedne strane, i pravila znanstvene zajednice, s druge strane, između društvenih obveza da njegova znanost bude korisna i profesionalne obveze da štiti integritet i razvoj svoje discipline (Nelkin, 1977, 75). Drugim riječima, znanstvenik je pod pritiskom i modela HE i modela HS, intrinzične motivacije i racionalnih ciljeva s jedne strane, te i etike odgovornosti i služenju općem dobru s druge. U Tablici 2 predložen je model znanstvenika kao HS u kojem se također analizira njegova društvena uloga i društvene vrijednosti i norme kulture društva u kojem djeluje na tri razine.

Tablica 2. Model znanstvenika kao homo sociologicusa

\begin{tabular}{|l|l|l|l|}
\hline & \multicolumn{1}{|c|}{ Društvena uloga } & $\begin{array}{c}\text { Društvene norme i } \\
\text { vrijednosti }\end{array}$ & $\begin{array}{l}\text { Kultura društva u } \\
\text { kojem djeluje }\end{array}$ \\
\hline $\begin{array}{l}\text { Individualna } \\
\text { razina }\end{array}$ & Osobna evolucija & $\begin{array}{l}\text { Društvena odgovornost } \\
\text { Osjetljivost } \\
\text { Održivost }\end{array}$ & $\begin{array}{l}\text { Doprinos društvenom } \\
\text { razvoju }\end{array}$ \\
\hline $\begin{array}{l}\text { Organizacijska } \\
\text { razina }\end{array}$ & Društvena korisnost & $\begin{array}{l}\text { Ideje i inovacije } \\
\text { Kulturni kapital }\end{array}$ & Kritičko mišljenje \\
\hline $\begin{array}{l}\text { Društvena/politička } \\
\text { razina }\end{array}$ & Znanost po mjeri društva & Društveni razvoj & $\begin{array}{l}\text { Društveno odgovorna } \\
\text { znanost }\end{array}$ \\
\hline
\end{tabular}

\section{Ponovno otkrivanje: znanstvenik kao homo academicus universalis}

Ako je znanost i znanstveni sustav vrhunac primjene principa racionalizacije $^{4}$ u nekom društvu, trebamo se zapitati treba li uopće racionalnost imati etičku dimenziju ili je racionalno amnestirano od etičkog. Na to pitanje nije jednostavno niti započeti raspravu, a kamoli dati odgovore jer nas to, između ostalog, vodi također i prema raspravama o kritici modernosti, povijesti postmoderne misli itd. Od mnoštva kritičara modernog društva koji se temelji na racionalnosti, svakako je među značajnijim Bauman koji je ukazao na

Max Weber definira racionalnost $u$ svojoj analizi tržišnog i ekonomskog djelovanja, a pod njom podrazumijeva opseg impersonal- ne kvantitativne kalkulacije koja je moguća $i$ primjenjiva u zadovoljenju potreba (Weber, 1978, 85). 
svu iracionalnost racionalnog pokazujući zastrašujuću tragediju Holokausta kao primjera »efikasnog « $\mathrm{i} »$ racionalnog « organizacijskog sustava za istrebljenje, čime racionalnost lišena humanosti dovodi do svoje iracionalnosti (Bauman,1989, 23). Primjena racionalnih znanstvenih metoda lišenih etičke dimenzije dovela je i do najvećih ratova i masakra u povijesti ljudskog roda u prošlom stoljeću, iako se ono podrazumijeva i kao razdoblje »modernog «, »progresivnog « i »prosvijetljenog«. U takvom pogonu, znanstvenik je sve više postao (i)racionalni objekt, a manje kreativni i odgovorni subjekt, puko oruđe za ispunjenje nehumanih ciljeva. Treba li uopće ponavljati (a očito treba) da su najznačajnije znanstvene inovacije i otkrića 20. stoljeća nastala u laboratorijima vojne industrije? I što je danas s eksperimentiranjem na ljudskom tkivu i stanicama, pokušajima kloniranja i križanja stanica različitih vrsta, rastućim pritiscima GMO industrije, itd. Foucault već odavno uviđa da je ključni problem u tome što znanje generira moć konstituirajući ljude kao subjekte samo u mjeri u kojoj upravljaju drugim subjektima pomoću znanja (Foucault, 1994). Ako je znanje proizvod rada znanstvenika, a ono služi kao sredstvo moći više nego kao sredstvo koje pospješuje sveopći društveni razvoj i opće dobro, zaista treba postaviti pitanje znanstvenicima tko su i trebaju li zauzimati strane. To je osobito naglašavao i Bourdieu u svojem konceptu homo academicus-a čija se moć temelji na dvjema vrstama kapitala: akademskom i intelektualnom (Bourdieu, 1988), pri čemu akademski kapital znači kontrolu nad materijalnim, organizacijskim i socijalnim instrumentima koji se reproduciraju na sveučilištima, a intelektualni podrazumijeva znanstveni prestiž definiran od i među kolegama u struci.

Nije uopće sporno da će akteri profita/koristi uvijek (racionalno) težiti izbjegavanju etičkih i moralnih principa, bez obzira bile to korporacije, vojne institucije ili međunarodne organizacije, o čemu je već davno pisao i Wright Mills u Elitama moći (Wright Mills, 1981), no ključno i gotovo presudno pitanje jest i trebalo bi biti koja je pritom uloga države kao demokratske institucije i zakona i »na čijoj su strani« razna tijela, zaklade, povjerenstva, komisije i agencije pri vladama širom svijeta. Država i njezine znanstvene institucije češce se ponašaju kao akteri promoviranja i zaštite interesa međunarodnih korporacija i organizacija nego akteri koji štite i služe svojim građanima, ali ni to nije neka novost. Zastrašujuća je i obeshrabrujuća spoznaja da su i znanstvenici postali tek puki kotačić u tom predvidljivom iracionalno-racionalnom mehanizmu »viših interesa«, na štetu javnog dobra. Oba modela (HE i HS) zapravo pokazuju djelovanje znanstvenika kao oruđa ili resursa za ispunjenje različitih osobnih i/ili društvenih ciljeva, bez istinskog propitivanja etičkog, moralnog, lišenog savjesti i odgovornosti koji kao kriteriji gotovo da uopće ne postoje $u$ vrednovanju rada znanstvenika i znanstvenih institucija. Ovaj rad ne može odgovoriti na pitanje zašto je tome tako, no na temelju navedenog žele se razmotriti i promovirati ideje o povratku novovjekovne ideje u kojoj je znanstvenik homo academicus (HA) tj. univerzalni čovjek koji kao koncept imperativno sadržava humanost, etičku dimenziju i poštivanje elementarnih univerzalnih vrijednosti o zaštiti čovjeka i prirode. Ako se već ne može očekivati da znanstvenik radi za neko dobro ljudima, može li očekivati da barem ne pristaje činiti štetu. Čini se da je to zapravo jedno od ključnih pitanja gdje treba tražiti izlaz iz razmatranih proturječnosti prva dva modela. Možda bi i svi znanstvenici trebali polagati nešto poput liječničke Hipokratove zakletve o tome da najprije neće nikome naškoditi (primum non nocere) i time se barem protokolarno obvezati na odbacivanja onih djelovanja koja dovode do destrukcije živih organizama i okoliša. 
Iako postoji tradicija kritičkog propitivanja uloge znanstvenika u društvu, što se osobito očituje u kritičkom pristupu u sociologiji znanosti (npr. Ben-David i Sullivan, 1975; Bourdieu, 1984) i puno je rasprava već napisano, tendencija da se potiče djelovanje znanstvenika kao HE formiranog prema scijentometrijskim modelima ukazuje također i na pasivnost akademske zajednice kako na lokalnoj, tako i na globalnoj razini uz nedovoljno angažiranje u promoviranju važnosti i vrijednosti javne korisnosti i djelovanja za opće dobro, što bi možda trebalo postati ključna varijabla koncepta izvrsnosti. Taj koncept znanstvenika kao homo academicusa trebao bi uključivati više tih kvalitativnih kriterija pri evaluaciji uspješnosti znanstvenika, ${ }^{5}$ a znanje kao produkt njegova rada treba »mjeriti« i korisnošću za opće dobro uz prihvaćanje znanstvenikove odgovornosti za svoj rad (Nelkin, 1977). To zahtijeva redefiniranje i proširenje varijabli iz scijentometrijskog modela u kojem bi se više vrednovala kvaliteta i znanstveni doprinos rada, nego impact factor časopisa u kojem je objavljen, kao i pozitivni učinak znanstvenikova rada za širu zajednicu i slično. Primjerice, kako scijentometrijski vrednovati slučaj kada vrhunski znanstvenik-neurokirurg uspješno primjeni endoskopsku metodu uklanjanja ugruška u mozgu bez operacije glave? To što je spasio brojne živote manje mu je bitno za njegovo napredovanje ako o tome nije napisao znanstveni rad $\mathrm{u}$ medicinskom časopisu s visokim impact factorom $\mathrm{i}$ ako nema dobar $h$-indeks. $\mathrm{U}$ tome je bitan aspekt apsurda i iracionalnosti današnje uloge znanstvenika i vrednovanja utemeljenog gotovo isključivo na scijentometriji koja takvom neurokirurgu ne vrednuje broj spašenih života već broj objavljenih radova.

Stoga, povratak načelima HA bi najprije trebao započeti već i u drugačijim modelima visokoškolskog obrazovanja koje će poticati, pa i nagrađivati ako je potrebno, upis bar nekih izbornih kolegija iz područja arts and humanities (Nussbaum, 2010) odnosno iz opće kulture, humanističkih disciplina koje razmatraju etička i moralna pitanja u znanosti te pristupe drugih kultura, bez obzira koje je područje studija major. Zato i suvremenu primjenu načela HA treba zapravo tražiti $u$ ishodištu te ideje u kojoj je objedinjen nastavni i znanstveni rad u vidu univerzalnog scholara. Još od Platonove akademije, preko nastavnog programa srednjovjekovnih škola koji se sastojao od ranije spomenutih sedam slobodnih vještina (septem artes liberales), postoji kontinuitet ideje općeg i humanističkog obrazovanja akademskih građana, koje je, kako tvrdi Nussbaum, zastupljenije danas u SAD-u više, nego u zemljama EU (Nussbaum, 2010). Nažalost, zemlje EU išle su u proteklih dvadesetak godina radikalno u suprotnom smjeru, uvodeći po posljedicama vrlo negativan bolonjski proces na sveučilišta čija je najveća i očita posljedica sustavna neobrazovanost (Liessmann, 2006) jer se opseg obvezne literature ograničava metrijskim modelom ECTS bodova, čime je čitanje kao temelj studiranja uspješno iskorijenjeno. Nussbaum stoga i razlikuje dvije suprotstavljene paradigme: obrazovanje za civilno građanstvo i obrazovanje za gospodarski rast, koje nisu isključive, nego je moguća integracija jer uzimaju najbolje iz modela HE i HS.

Npr. evaluacija nastavničkog rada od strane studenata se uopće kod nas ne uzima kao kriterij za napredovanje, a primjerice monografija koja bi trebala biti kruna rada znanstvenika u društvenim se znanostima gotovo omalovažava i tretira tek kao tri rada A2 kategorije, što je očita diskriminacija. Također, nije jasno zašto je u Hrvatskoj Current Contents kao primarno baza znanstvenih radova u prirodnim znanostima, nametnuta i društvenim znanstvenicima kao kriterij izvrsnosti te tko je kada i zašto tako odlučio te zašto je akademska zajednica na to pristala. 
Ovaj treći model HA stoga predlaže moguće »pomirenje« i rješenje problema podijeljenosti znanstvenika između različitih društvenih uloga, polazeći od inkluzije tj. uključivanja elemenata i jednog i drugog modela. Drugim riječima, polazi se od integracije korisnih znanja i vještina i za tržište i za opće dobro, a homo academicus postaje univerzalniji čovjek u odnosu na ranije varijante. U Tablici 3 prikazan je model znanstvenika kao homo academicusa.

Tablica 3. Model znanstvenika kao homo academicusa

\begin{tabular}{|l|l|l|l|}
\hline & \multicolumn{1}{|c|}{ Društvena uloga } & \multicolumn{1}{|c|}{$\begin{array}{c}\text { Društvene norme i } \\
\text { vrijednosti }\end{array}$} & $\begin{array}{l}\text { Kultura društva u } \\
\text { kojem djeluje }\end{array}$ \\
\hline Individualna razina & $\begin{array}{l}\text { Znanstvenik kao } \\
\text { savjest društva }\end{array}$ & $\begin{array}{l}\text { Savjesnost } \\
\text { Odgovornost } \\
\text { Moral } \\
\text { Etika }\end{array}$ & $\begin{array}{l}\text { Kultura utemeljena } \\
\text { na univerzalnim } \\
\text { vrijednostima }\end{array}$ \\
\hline $\begin{array}{l}\text { Organizacijska } \\
\text { razina }\end{array}$ & $\begin{array}{l}\text { Društveno odgovorno } \\
\text { Poslovanje }\end{array}$ & $\begin{array}{l}\text { Solidarnost i humanitarno } \\
\text { sponzorstvo }\end{array}$ & $\begin{array}{l}\text { Spoj racionalnog i } \\
\text { kritičkog mišljenja }\end{array}$ \\
\hline $\begin{array}{l}\text { Društvena/politička } \\
\text { razina }\end{array}$ & $\begin{array}{l}\text { Korisnost za sve } \\
\text { društvene skupine }\end{array}$ & $\begin{array}{l}\text { Održiva znanost } \\
\text { Znanje kao resurs } \\
\text { održivog rasta i razvoja }\end{array}$ & $\begin{array}{l}\text { Kultiviranje } \\
\text { humanosti6 }\end{array}$ \\
\hline
\end{tabular}

\section{Vanjski pritisci tržišnog društva: znanost i znanje kao roba}

Brojne su izvanjske tenzije suprotstavljenih smjerova s kojima se znanstvenik danas suočava i o kojima bi se mogle napisati i zasebne rasprave: znanstvenik u službi profita $v s$. u službi općeg dobra; znanstvenik kao profesionalac $v s$. znanstvenik kao aktivist civilnog društva; između korporacijskog interesa i šireg društvenog interesa; između rada za eksploataciju i rada za održivi razvoj; između profita kao prioriteta i znanstvene spoznaje per se; između epistemologije i zdravog razuma; znanstvenik u postmodernom diskursu vs. znanstvenik u modernom diskursu; znanstvenik kao ideolog vs. znanstvenik kao stručnjak; znanstvenik kao evaluator i kao evaluirani; znanstvenik kao aktivni akter, kreator i subjekt vs. pasivni akter, izvršitelj i objekt itd. Iako svaka od navedenih tenzija zasigurno ima određenu ulogu u izborima koje znanstvenik mora učiniti, nameće se ipak jedna dominantna tenzija vezana uz činjenicu da on djeluje u tržišnom društvu ${ }^{7} u$ kojem se gotovo sve nastoji pretvoriti $u$ robu, a sve što nema tržišnu vrijednost, postaje društveno irelevantno. Dva su ključna procesa koja dovode to takvog stanja: na makro društvenoj razini to je marketizacija, ${ }^{8}$ a na mikro razini komodifikacija. Ako proces marketizacije označava jedan dugotrajni historijski društveni proces strukturalne i sociokulturne transformacije na makro društvenoj razini koji stvara strukture, institucije i pravni okvir, mjerljive konzekvence tog procesa na mikro razini se očituju u proširenju koncepta robe od materijalnih proizvoda i usluga pa do međuljudskih odnosa, znanja i znanosti, simboličkih značenja (brandova), prodaje osobnosti i nekih nematerijalnih resursa postindustrijskog doba kao što su npr. doživljaj, ugođaj, događaj i iskustvo (Pine, Gilmore, 2004). A taj proces pretvaranja nekog materijalnog predmeta ili osobnog umijeća u robu na tržištu jest poznat pod terminom komodifikacija koja u društvu znanja osobito obuhvaća znanost i znanstvenike, ali i sveučilišta, profesore i studente.

U takvom okružju marketizacije i komodifikacije, znanost kao društveni sustav i znanje kao proizvod rada znanstvenika dobivaju izrazitu tržišnu vrijednost (Massy, 2009), čime se znanstveniku u potpunosti promijenila društvena 
uloga pa je sada umjesto izumitelja i pedagoga u novoj ulozi proizvođača intelektualnog kapitala kao temelja marketiziranog društva znanja. Time je ljudski um postao po prvi puta u povijesti izravna proizvodna snaga, a računala, komunikacijski sustavi i programiranje postali su pojačala i produžeci ljudskog uma (Castells, 2000) kao što su u industrijskom dobu strojevi zamjenjivali fizički i manualni rad. Osim toga, rezultati znanstvenog istraživanja sve više postaju privatno, a ne javno dobro, bivaju zaštićeni kao poslovna tajna, patent ili intelektualno vlasništvo. Takva patentom zaštićena tehnološka informacija ima presudnu ulogu u stvaranju tržišne prednosti pred konkurencijom, pa su najprestižniji i najbogatiji centri za istraživanje i razvoj češće smješteni u određenim geografskim područjima i u nekim poduzećima i ustanovama, nego na javnim i državnim sveučilištima (Castells, 2000).

Problem je što glavni akter te transformacije društvene uloge znanosti i znanstvenika nisu bili niti poslovni sektor niti sveučilišta, nego prvenstveno država i njezine znanstvene i paraznanstvene institucije (npr. razne agencije za vrednovanja, fondovi i zaklade za znanost), koja se kao najvažnija institucija društva »pobrinula« da znanstveni sustav treba više služiti profitu, nego javnom/općem dobru. U evaluacijama rada znanstvenih instituta i fakulteta sve više postaje važan indikator da znanstvenik na svojem projektu ili organizacija u kojoj je zaposlen pruža potporu transferu tehnologije kroz kvalitetan sustav i administrativnu podršku za komercijalizaciju rezultata te da surađuje s privatnim sektorom. Na taj se način Ministarstvo ograđuje od obveza financiranja i forsira se primarno djelovanje znanosti za tržišne naručitelje pa ostaje dojam kao da političkom sustavu znanost zapravo više i ne treba jer naprosto ne zna što bi s njom. Stoga, nameće se još jedno u nizu pitanja: ako je znanost u suvremenim društvima samo zajednički nazivnik za institucionalni sustav koji treba najviše služiti privrednom sektoru i više ne omogućuje ljudskoj inteligenciji i kognitivnim sposobnostima općenito da se realiziraju, pitanje je ima li u 21. stoljeću znanost uopće još društvenu ulogu za opće dobro. Osim što je država postepeno digla ruke od znanosti, očito je da državna tijela sve manje financiraju i naručuju direktna istraživanja od znanstvenih institucija, osim onih koji se tiču političkog rejtinga i javnog mnijenja o političkim preferencijama. Također vjerujemo da država i njezine institucije tj. dužnosnici i službenici možda i ne znaju da im osobito društveni i humanistički znanstvenici mogu pružiti čitav niz korisnih znanja i informacija za donošenje kvalitetnih i manje rizičnih odluka, pa se za te usluge obraćaju preskupim ekspertima u privatnim consulting tvrtkama. A to bi se moglo poboljšati vrlo jednostavno tako da se u vladinim uredima i ministarstvima zaposle osobe koje bi pratile znanstvenu produkciju i spoznaje iz njihove nadležnosti i tematike te koje bi pripremale korisne informacije za bilo koju razinu donošenja odluke utemeljene na tim spoznajama. Rezultati istraživanja u društve-

6

Autorica je ove ideje također Martha Nussbaum iz istoimene knjige: Cultivating Humanity - A Classical Defense of Reform in Liberal Education (Nussbaum, 2000).

7

Slater i Tonkiss definiraju tržišno društvo kao društvo u kojem u svim njegovim dimenzijama dominira monetarna razmjena dobara što pak dovodi do sasvim novoga društvenog poretka, ali i društvene integracije kroz nove oblike političkih, društvenih i kulturnih organizacija (Slater, Tonkiss, 2004, 7).
8

Marketizaciju možemo shvatiti kao proces društvene preobrazbe $\mathrm{u}$ kojem i društvena struktura i društvene vrijednosti počinju djelovati prije svega i s tendencijom da to bude $\mathrm{i}$ isključivo u funkciji tržišta (pri čemu je znanost odigrala također važnu ulogu), njegovih načela $\mathrm{i}$ interesnih skupina kojima to ide $\mathrm{u}$ prilog (Polanyi, 1944; Tonkis, Slater, 2006; Peračković, 2008) 
nim znanostima donose uvide i spoznaje, odnosno korisne informacije, čiji je domet najčešće samo objavljivanje u znanstvenim časopisima, a koje mogu značajno doprinijeti pri donošenju dobrih ili barem manje rizičnih odluka. Stoga, ta temeljna izvanjska tenzija s kojom se znanstvenik suočava zapravo i više nije u dosegu njegova osobnog izbora u biranju strane. Prepušten tržištu, znanstvenik i sam postaje roba, postaje akademski poduzetnik kojemu su sve više korisnija stručna znanja iz menadžmenta ili marketinga nego primjerice znanja iz umjetnosti i humanistike, dakle opća kultura.

\section{Zaključak}

Budući da je djelovanje suvremena znanstvenika utemeljeno uglavnom na pozitivističkom pristupu uz redukciju kritičkog mišljenja, a ciljevi sve više ograničeni na korisnost i profit samo za manji broj interesnih skupina, na temelju prikazanog može se konstatirati da postaje sve više upitna jedna od temeljnih uloga znanstvenika u (post)modernom društvu, a to je zalaganje za opće ljudski napredak i blagostanje. S druge strane, stvorilo se jedno gotovo fundamentalističko religijsko vjerovanje u sposobnost i progresivnost tehnologije i znanosti da rješavaju ljudske probleme i poboljšavaju kvalitetu života, no pravo je pitanje za koju cijenu. Ako je pobijedila, uvjetno rečeno racionalnost znanstvenika kao HE koja dovodi do iracionalnosti očite u primijenjenoj znanosti za uništenje (industrijsko zagađenje, ratovi, klimatske promjene, kloniranje, GMO, itd.), to pak nužno opet dovodi do etičkog propitivanja uloge znanosti u društvu, ali i obrazovanja i njegovih ciljeva općenito. Budući da se profesionalizacija rada znanstvenika i znanstvenog sustava odvijala u dvjestogodišnjem historijskom kontekstu koncepta modernosti, utemeljenog na idejama kao što su racionalnost, svrhovitost, progres, konstrukcija, sinteza i determinacija itd., time se lakše može razumjeti ta geneza i evolucija uloge znanstvenika prema modelima HE i HS. Međutim, ako je druga polovica 20. stoljeća obilježena transformacijom modernog k postmodernom, ${ }^{9}$ čije su ideje suprotstavljene konceptu modernog, kao što su npr. iracionalnost, igranje, dekonstrukcija, antiteza i indeterminizam (Ritzer, 2004, 598), te promjene otvaraju mogućnosti i za rekonceptualizaciju uloge znanstvenika u društvu ali i njegovu (re)konstrukciju. Ovdje se ne zalažemo za potpuno odbacivanje tih ranijih principa i modela, niti forsiranje neke nove ideologije postmodernog znanstvenika koji sada primarno istražuje ezoterijsko, nadnaravno, paranormalno i slično, nego smatramo da suvremeni znanstvenik kao HA treba integrirati neke elemente i iz postojećih modela, dakle HE i HS uz propitivanje prioriteta i obaveznu integraciju univerzalnih etičkih i moralnih principa. Iako i od utopija ne treba odustati te iz njih treba crpiti smjernice i ideje, no u realnom svijetu treba razmatrati realna i održiva rješenja. Za takvu integraciju modela prema modelu HA, potrebna je temeljita reforma znanstvenog sustava, i to u onim fundamentalnim postavkama: vizija, misija, ciljevi, vrijednosti, u čemu presudnu ulogu ima država, od izrade strategije, financijske potpore, ali i vrijednosne transformacije od tržišnog k humanističkom društvu.

U tom smislu možemo govoriti i o postmodernom znanstveniku koji nipošto ne smije zanemariti i pozitivistički pristup kao temelj znanstvenog istraživanja, no morao bi sve više uključivati, osobito u početnoj fazi promišljanja istraživačkog problema i imaginaciju, kritičko mišljenje te neformalni razgovor s kolegama kao i s onima iz drugih struka; ne samo pretraživati »relevantne« baze podataka i radova, nego više poznavati društvenu memoriju i iskustva realnog svijeta života, subjektivnog iskustva ljudi na koji se istraži- 
vački problem odnosi, uključivati i osobne intuicije, kvalitativne metode, itd. Primjerice, metodološki pritisak koji je u društvenim znanostima nametnula primjena multivarijantne statistike doveo je do apsurda u kojem postoji nepisano pravilo da neka društvena pojava nije znanstveno relevantna ako na nju ne možemo primijeniti npr. faktorsku analizu. To naravno ne znači da te metode treba odbaciti, no one trebaju postati tek zadnja faza i sredstvo koje se može koristiti ako je teorijska konceptualizacija bila kvalitetno i sveobuhvatno promišljena i ako je operacionalizacija teorije $u$ istraživački instrumentarij adekvatno obuhvatila sve lokalne specifičnosti istraživane pojave. Znanstvenici su opterećeniji time i važnije im je da je instrument međunarodno standardiziran i validiran i da je preuzet od uglednog stranog znanstvenika ili sveučilišta, nego pitanjem je li instrument obuhvatio konkretnu društvenu stvarnost i specifična obilježja sredine, realnost, percepciju problema i iskustvo aktera, pa su nažalost, rijetka istraživanja koja kombiniraju barem u pilot-fazi kvalitativni i kvantitativni pristup kao i sekundarne izvore. I na kraju, možda još treba samo podsjetiti da je u tri, nažalost zaboravljene kratke rečenice jedan od najvećih umova u ljudskoj povijesti, Albert Einstein ove tenzije na neki način nadišao, ponudio odgovore, zacrtao smjer te istaknuo što je prioritet:

»Mašta je važnija od znanja. Znanje je ograničeno. Mašta okružuje svijet. «10

To bi znanstvenici u 21. stoljeću tek trebali otkriti, a bilo bi poželjno i prihvatiti kao jedan od svojih temeljnih principa u radu.

\section{Literatura}

Archer, M. S., Tritter, J. Q. (2000): Rational Choice Theory: Resisting Colonisation. London: Routledge. doi: https://doi.org/10.4324/9780203133897.

Bauman, Z. (1989): Modernity and the Holocaust. Ithaca (NY): Cornell University Press.

Ben-David, J., Sullivan, T. A. (1975): »Sociology of Science« Annual Review of Sociology 1 (1/1975), str. 203-222. doi: https://doi.org/10.1146/annurev.so.01.080175.001223.

Ben-David, J. (1971): The Scientist's Role in Society. Englewood Cliffs (NY): PrenticeHall.

Boudon, R. (1981): The Logic of Social Action: An Introduction to Sociological Analysis. London: Routledge and Kegan Paul.

Bourdieu, P. (1988): Homo Academicus. Palo Alto: Stanford University Press.

Bourdieu, P. (2004): Science of Science and Reflexivity. Chicago: University of Chicago Press.

Castells, M. (1997): The Rise of the Network Society. Oxford: Blackwell Publishers Inc.

To se osobito očituje i u onom što filozofi i sociolozi nazivaju postmodernim obilježjima suvremenih društava još od 60-ih godina 20. stoljeća (Marshall, 1998, 511), kada ljudi sve više počinju gubiti vjeru u znanost i tehnologiju, postaju ekološki svjesni zbog iskustva štetnog djelovanja zagađenja, opasnosti nuklearne energije, rizika genetskog inženjerstva na ljude i prirodu. Stoga, sve više raste sumnja u korisnost racionalne znanosti i svrhe znanstvenog rada, nastaju nove alternativne kulture i stilovi života koji se udaljavaju od znanosti i racionalnog te promoviraju neracionalno mišljenje (što je adekvatniji termin od iracionalnog koji ima više negativno značenje), neznanstveno znanje, imaginaciju, kritičko propitivanje, retradicionalizaciju, new age duhovnost, povratak religiji, itd. 10

Ovaj je citat i dokumentiran, jer se pojavljuje u intervjuu G. S. Vierecka s A. Einsteinom koji je tiskan 1929. u magazinu Saturday Evening Post: George Sylvester Viereck, "What Life Means to Einstein«, Saturday Evening Post (26 Oct 1929), 117. Reprint u Viereck, Glimpses of the Great (1930, 447). 
Curtius, E. R. (1973): European Literature and the Latin Middle Ages. Princeton: Princeton University Press.

Dahrendorf, R. (1961): »Democracy without Liberty«. U: Lipset, S. M., Lowenthal, L. (ur.): Culture and Social Character: The Work of David Riesman Reviewed. New York: Free Press of Glencoe, Inc.

Dixon, W., Wilson. D. (2012): A History of Homo Economicus: The Nature of the Moral in Economic Theory. London: Routledge. doi: https://doi.org/10.4324/9780203142875.

Drucker, P. (1939): The End of Economic Man. New York: The John Day Company.

Einstein, A. (1292): »What life means to Einstein«. U: Viereck, G. S. (intervju): The Saturday Evening Post (26. 8. 1929), str. 117. Dostupno na: http://www.saturdayeveningpost. com/wp-content/uploads/satevepost/what life means to einstein.pdf (pristupljeno 7. 12. 2015.).

Fehr, E., Gächter, S. (1998): »Reciprocity and economics: The economic implications of Homo Reciprocans«. European Economic Review 42 (3-5/1998), str. 845-859. doi: https:// doi.org/10.1016/s0014-2921(97)00131-1.

Foucault, M. (1994): Znanje i moć. Zagreb: Globus.

Hamlin, C. L. (2012): Beyond Relativism: Raymond Boudon, Cognitive Rationality and Critical Realism. London: Routledge. doi: https://doi.org/10.4324/9780203167533.

Haralambos, M., Heald, R. (1989): Uvod u sociologiju. Zagreb: Globus

Henrich, J., Boyd, R., Bowles, S., Camerer, C., Fehr, E. i sur. (2001): »'Economic man' in Cross-cultural perspective: Behavioral experiments in 15 small-scale Societies«. Behavioral and Brain sciences 28 (6/2001), str. 795-855. doi: https://doi.org/10.1017/ s0140525x05000142.

Hirsch, P., Michaels, S., Friedman, R. (1990): „Clean Models vs. Dirty Hands: Why Economics is Different from Sociology?«. U: Zukin, S., DiMaggio, P. (ur.): Structures of Capital: The Social Organization of the Economy. Cambridge: Cambridge University Press, str. 39-56.

Jurić, H. (2012): »Multi-disciplinarity, pluri-perspectivity and integrativity in the science and the education«, The Holistic Approach to Environment 2 (2/2012), str. 85-90.

Liessmann, K. P. (2008): Teorija neobrazovanosti: zablude društva znanja. Zagreb: Naklada Jesenski i Turk.

Marshall, G. (ur.) (1998): A Dictionary of Sociology. Oxford: Oxford University Press.

Massy, W. F. (2009): »Academic Values in the Marketplace«. Higher Education Management and Policy 21 (3/2009), str. 59-74. doi: https://doi.org/10.1787/hemp-21-5ksdxgp5hrzv.

Milardović, A. (2011): Druga moderna: fragmenti o kulturi zapada. Zagreb: Pan liber.

Mill, J. S. (1874): »On the Definition of Political Economy, and on the Method of Investigation Proper to It«. London and Westminster Review. Essays on Some Unsettled Questions of Political Economy. London: Longmans, Green, Reader \& Dyer.

Mills, C. W. (1981): The Power Elite. London: Oxford University Press.

Nelkin, D. (1977): »Scientists and Professional Responsibility: The Experience of American Ecologists«. Social Studies of Sceince 7 (1/1977), str. 579-595. doi: https://doi.org/10 $.1177 / 030631277700700103$.

Parker, H. (1890): »The Seven Liberal Arts«. The English Historical Review V (XIX/1890), str. 417-461. doi: https://doi.org/10.1093/ehr/v.xix.417.

Nussbaum, M. (2012): Ne profitu. Zašto demokracija treba humanistiku. Zagreb: AGM.

Nussbaum, M. (2000): Cultivating Humanity - A Classical Defense of Reform in Liberal Education. Harvard: Harvard University Press.

O’Boyle, E. J. (2007): »Requiem for Homo Economicus«. Journal of Markets \& Morality 10 (2/2007), str. 321-337. Dostupno na: http://www.marketsandmorality.com/index. $\mathrm{php} / \mathrm{mandm} /$ article/viewFile/235/225 (pristupljeno 7. 12. 2015.). 
Peračković, K. (2008): »Društvo i (ili) tržište - sociološka konceptualizacija procesa marketizacije društva«. Društvena istraživanja 17 (6/2008), str. 975-998.

Persky, J. (1995): »Retrospectives: The Ethology of Homo Economicus«. The Journal of Economic Perspectives 9 (2/1995), str. 221-231. doi: https://doi.org/10.1257/jep.9.2.221.

Pine, B. J., Gilmore, J. H. (1999): The Experience Economy. Boston: Harvard Business School Press.

Polanyi, K. (1944): The Great Transformation: The Political and Economic Origins of Our Time. Boston: Beacon Press.

Polšek, D. (2015): Contra paedagogicos. Ideja o liberalnom obrazovanju. Zagreb: Institut društvenih znanosti Ivo Pilar.

Ritzer, G., Goodman, D. J. (2004): Sociological Theory. Boston: McGrow Hill.

Slater, D., Tonkiss, F. (2004): Market Society. Cambridge: Polity Press.

Smith, Adam (1852): An Inquiry into the Nature And Causes of the Wealth of Nations. London: T. Nelson and Sons, Paternoster Row.

Švarc, J. (2009): Hrvatska u društvu znanja: prijepori i perspektive inovacijske politike, Zagreb: Školska knjiga.

Viereck, G. S. (1930): Glimpses of the Great. New York: Macaulay Co.

Wagner, D. L. (1983): The Seven Liberal Arts in the Middle Ages. Bloomington: Indiana University Press.

Weber, M. (1978): Economy and Society. Berkeley: University of California Press.

\title{
Krešimir Peračković
}

\section{The Social Role of Scientists Today}

\section{Scientist as Homo Economicus and Homo Sociologicus} versus Homo Academicus Universalis

\begin{abstract}
This paper critically examines some aspects of the role of scientists in modern society, starting from the different expectations from scientists under various outside pressures: scientometry, social responsibility and humanistic tasks. In considering the social framework and norms that guide the actions of scientists, firstly we will summarize possible approaches to the roles of scientists as homo economicus and homo sociologicus, which could be used as ideal-type templates for the development of the model that analyses both the role of scientists in features of utility, profit and rationality at the individual, organizational and socio-political level. After that we will show an integrative model of homo academicus universalis, which integrates and reconciles some characteristics of the previous two models, and brings some old humanistic ideals of a scientist as a universal human being. At the end, we briefly analyse the social context: the market society in which the prevailing tendency is that science is becoming fully commodified as well.
\end{abstract}

\section{Key words}

homo economicus, homo sociologicus, homo academicus, commodification of knowledge, knowledge society, market society, sociology of science, unversalis 